Bond University

Research Repository

\title{
Beyond Sodium, Phosphate and Potassium: Potential Dietary Interventions in Kidney Disease
}

Kelly, Jaimon T.; Rossi, Megan; Johnson, David W.; Campbell, Katrina L.

\section{Published in:}

Seminars in Dialysis

DOI:

10.1111/sdi.12580

Licence:

Other

Link to output in Bond University research repository.

Recommended citation(APA):

Kelly, J. T., Rossi, M., Johnson, D. W., \& Campbell, K. L. (2017). Beyond Sodium, Phosphate and Potassium: Potential Dietary Interventions in Kidney Disease. Seminars in Dialysis, 30(3), 197-202. https://doi.org/10.1111/sdi.12580

\footnotetext{
General rights

Copyright and moral rights for the publications made accessible in the public portal are retained by the authors and/or other copyright owners and it is a condition of accessing publications that users recognise and abide by the legal requirements associated with these rights.
}

For more information, or if you believe that this document breaches copyright, please contact the Bond University research repository coordinator. 
This is the peer reviewed version of the following article: Kelly, J. T., Rossi, M., Johnson, D. W., \& Campbell, K. L. (2017). Beyond Sodium, Phosphate and Potassium: Potential Dietary Interventions in Kidney Disease. Seminars in Dialysis, 30(3), 197-202, which has been published in final form at https://doi.org/10.1111/sdi.12580.

This article may be used for non-commercial purposes in accordance with Wiley Terms and Conditions for Use of Self-Archived Versions.

\section{Beyond Sodium, Phosphate and Potassium: Potential Dietary Interventions in kidney Disease}

Jaimon T. Kelly, ${ }^{1}$ Megan Rossi, ${ }^{2}$ David W. Johnson, ${ }^{3,4,5}$ Katrina L. Campbell ${ }^{1,6}$

\section{Affiliations}

1. Faculty of Health Sciences and Medicine, Bond University, Gold Coast, Australia

2. Diabetes and Nutritional Sciences Division, Kings College London, UK

3. Department of Nephrology, Princess Alexandra Hospital, Brisbane, Australia

4. Diamantina Institute, University of Queensland, Brisbane, Australia

5. Translational Research Institute, Brisbane, Australia

6. Department of Nutrition and Dietetics, Princess Alexandra Hospital, Brisbane, Australia

\section{Funding}

Nil

\section{Conflict of Interest}

None.

\section{Corresponding author}

\section{Katrina L Campbell, kcampbel@bond.edu.au}

Faculty of Health Science and Medicine, Bond University

14 University Drive, Robina, Queensland, 4226, Australia

Word count (excluding title page, abstract and references): 2,880 
This is the peer reviewed version of the following article: Kelly, J. T., Rossi, M., Johnson, D. W., \& Campbell, K. L. (2017). Beyond Sodium, Phosphate and Potassium: Potential Dietary Interventions in Kidney Disease. Seminars in Dialysis, 30(3), 197-202, which has been published in final form at https://doi.org/10.1111/sdi.12580.

This article may be used for non-commercial purposes in accordance with Wiley Terms and Conditions for Use of Self-Archived Versions.

\begin{abstract}
People with kidney disease are advised to restrict individual nutrients, such as sodium, potassium and phosphate, in line with current best practice guidelines. However, there is limited evidence to support the efficacy of single nutrient strategies, and compliance remains a challenge for clinicians to overcome. Many factors are known to contribute to poor compliance with dietary prescriptions, including conflicting priorities for single nutrient restriction, the arduous self-monitoring required, and the health-related knock-on effects resulting from targeting these nutrients in isolation. This paper reviews the evidence-base for the overall pattern of eating as a potential tool to deliver a diet intervention in which all the nutrients and foods work cumulatively and synergistically to improve clinical outcomes. These interventions may assist in kidney disease management and overcome these innate challenges that single nutrient interventions possess. The characteristics of healthy dietary patterns are that they are typically plant-based and lower in sodium and animal proteins. These patterns may have numerous mechanistic benefits for cardiovascular health in kidney disease, most notably through the increase in fruit, vegetables, and a higher protein ratio from plant-based sources, and improved gut health through the increase in dietary fiber. The evidence to date for dietary patterns points towards a predominant plant-based diet, and suggests these diet interventions may better translate to improved clinical outcomes in kidney disease. However, for this type of dietary pattern to be translated into practice, clinical trials are needed to determine whether these diet interventions are feasible, safe and effective in the management of kidney disease.
\end{abstract}


This is the peer reviewed version of the following article: Kelly, J. T., Rossi, M., Johnson, D. W., \& Campbell, K. L. (2017). Beyond Sodium, Phosphate and Potassium: Potential Dietary Interventions in Kidney Disease. Seminars in Dialysis, 30(3), 197-202, which has been published in final form at https://doi.org/10.1111/sdi.12580.

This article may be used for non-commercial purposes in accordance with Wiley Terms and Conditions for Use of Self-Archived Versions.

\section{Background}

Diet has long been considered a modifiable risk factor for chronic kidney disease (CKD), and a key management strategy in end-stage kidney disease (ESKD). International guidelines for managing kidney disease have traditionally focused on the modification of the macro- and micro-nutrients such as protein, energy, sodium, potassium, phosphorous, and types of macronutrients, including fatty acids and sugars. ${ }^{1,2}$ This approach of individual nutrient modification can result in complex nutrition messages. Translating these into clear food-based recommendations is challenging. It comes as little surprise that food and fluid advice have been reported as ambiguous and frustrating by patients, ${ }^{3}$ inherently restrictive ${ }^{4}$ and have been shown to adversely impact overall diet quality. ${ }^{5}$

The aim of dietary management in patients with early stage CKD is to delay progression and reduce cardiovascular risk. Conversely, in dialysis patients, the focus is to mitigate proteinenergy wasting and electrolyte disturbances (i.e. low potassium, low phosphorous, high calorie). ${ }^{6}$ In contrast, a traditional cardio-protective diet targeting higher fiber, and lower saturated fat may be considered to be in direct conflict with low electrolyte and high calorie advice in CKD management. ${ }^{7}$ Adopting an alternative whole-of-diet approach, which shifts focus onto foods, such as wholegrains, fruits, and vegetables, shows considerable promise with respect to pragmatically and effectively achieving the universal goals of retarding CKD progression and attenuating cardiovascular risk, whilst still avoiding serious electrolyte derangements..$^{4,8}$

This paper will consider historical evidence for individual nutrient-based restrictions, appraise and contrast new evidence and controversies, and discuss emerging, whole-of-diet strategies for the management of kidney disease and its complications.

\section{Challenges with traditional individual nutrient approaches to nutrition management}


This is the peer reviewed version of the following article: Kelly, J. T., Rossi, M., Johnson, D. W., \& Campbell, K. L. (2017). Beyond Sodium, Phosphate and Potassium: Potential Dietary Interventions in Kidney Disease. Seminars in Dialysis, 30(3), 197-202, which has been published in final form at https://doi.org/10.1111/sdi.12580.

This article may be used for non-commercial purposes in accordance with Wiley Terms and Conditions for Use of Self-Archived Versions.

Current international guidelines recommend patients receive individualised dietary interventions by a qualified dietitian focusing on individual nutrients, including salt, phosphate,

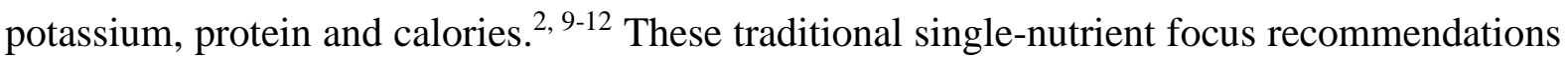
present four key issues:

a) Poor evidence base underpinning individual nutrient strategies

Most studies examining individual nutrient modification strategies have been limited in methodologic quality. Studies in nutritional nephrology are plagued by small sample sizes, short follow-up and use of non-validated surrogate outcome measures, ${ }^{2,}{ }^{13-17}$ such that the effects of these approaches on patient-level outcomes, including ESKD and mortality, remain uncertain. For example, dietary salt reduction is considered a key dietary strategy in kidney disease, with strong evidence supporting a role for augmenting the pharmacological effects of antihypertensive medications and reducing blood pressure and albuminuria. However, the effects of long-term salt restriction on CKD progression and cardiovascular outcomes remain uncertain. ${ }^{17-22}$ Similarly, dietary phosphate restriction has been advocated by many guidelines to ameliorate renal and cardiovascular risk. However, the evidence that change to dietary phosphorus intake can impact outcomes beyond serum measures is notably absent. ${ }^{23,24}$ Dietary potassium restriction for the prevention and management of hyperkalaemia is further advocated, particularly in more advanced forms of CKD, and ensuing cardiac arrhythmias. However, to date there have been no randomised-controlled trials evaluating the impact of potassium restriction on clinical events. In contrast, increased dietary potassium consumption is advocated in concert with dietary sodium restriction to reduce cardiovascular risk in the general population. ${ }^{25}$ There is observational evidence of the benefits of this in CKD models on $\mathrm{CV}$ risk factors, ${ }^{26}$ which provides further uncertainty. 
This is the peer reviewed version of the following article: Kelly, J. T., Rossi, M., Johnson, D. W., \& Campbell, K. L. (2017). Beyond Sodium, Phosphate and Potassium: Potential Dietary Interventions in Kidney Disease. Seminars in Dialysis, 30(3), 197-202, which has been published in final form at https://doi.org/10.1111/sdi.12580.

This article may be used for non-commercial purposes in accordance with Wiley Terms and Conditions for Use of Self-Archived Versions.

Modified protein diets continue to be at the forefront of nutritional management for people with kidney disease. Low protein diets are favoured in CKD for ameliorating uraemia, kidney stone formation, gout, hyperphosphatemia, and gut-derived uremic toxins. ${ }^{27}$ However, protein restriction trials report inconsistent findings and at best, provide a modest benefit for progression to $\mathrm{ESKD}^{28}$ or mortality. ${ }^{29}$ Meta-analysis shows protein reductions of $0.2 \mathrm{~g} / \mathrm{kg} / \mathrm{day}$ delay CKD progression by only $0.5 \mathrm{~mL} / \mathrm{min} /$ year in both randomised and non-randomised trials. ${ }^{30}$ In addition, compliance with low protein diets is poor, ${ }^{5,31}$ and can risk protein-energy wasting. ${ }^{30,} 32$ It should therefore come as no surprise that there is a paucity of evidence supporting the assertion that low protein diets reduce the risk of progression to $\mathrm{ESKD}^{28}$ or mortality. ${ }^{29}$ As in CKD, the majority of evidence in dialysis is based on observational studies, and in many instances the target protein intakes are rarely achieved. ${ }^{33}$ This continues to challenge guidelines committees tasked with designing evidence-based protein recommendations.

\section{b) Complex nutritional interventions impair dietary adherence}

Individual nutrient modification can lead to complex nutritional messages, which people with kidney disease report to be confusing and constraining. ${ }^{3-5,34}$ Patients with CKD report dietary interventions to be burdensome $\mathrm{e}^{35}$ leading to overall poor adherence to dietary restrictions. ${ }^{5,36}$ A number of characteristics are known to influence a patient's ability to follow dietary recommendations, including a patient's knowledge, self-efficacy, motivation, and uremicrelated factors. ${ }^{37}$ Poor dietary adherence in CKD and dialysis populations may therefore place patients at risk of clinical complications, such as malnutrition, fluid overload and CVD. ${ }^{5,36,38}$

\section{c) Conflict between competing priorities of individual nutrient strategies}

When adopting an individual nutrient approach, translating these recommendations to foodbased advice can create conflicting priorities. A key example is between dietary protein and 
This is the peer reviewed version of the following article: Kelly, J. T., Rossi, M., Johnson, D. W., \& Campbell, K. L. (2017). Beyond Sodium, Phosphate and Potassium: Potential Dietary Interventions in Kidney Disease. Seminars in Dialysis, 30(3), 197-202, which has been published in final form at https://doi.org/10.1111/sdi.12580.

This article may be used for non-commercial purposes in accordance with Wiley Terms and Conditions for Use of Self-Archived Versions.

phosphorous. In dialysis, a high protein intake with optimal phosphate management is associated with the best survival. ${ }^{39}$ However, advice to increase protein intake to prevent protein-energy wasting may in fact introduce an increase in phosphorous intake due to the high phosphorous content in protein sources. As a result, this approach can compete with an increased risk of hyperphosphatemia. ${ }^{39}$

\section{d) Health-related knock-on effects from restricting single nutrients}

As mentioned above, despite the evidence-base supporting the restriction of single nutrients, this is a challenging and complex task for people with kidney disease. In addition, the practical application of these individual nutrient restrictions can compromise the overall quality of the diet and be detrimental to one's health. For example, a dialysis patient may be instructed to restrict their potassium intake by fruits, vegetables and whole grains. The 'knock-on' consequences impact both nutrition and overall health. For example, avoiding these foods reduces the exposure to dietary fiber, limiting its therapeutic role in preventing constipation and as a pre-biotic in maintaining a healthy gut microbiome. ${ }^{40}$

Therefore, quantifying nutrient intake is not only a challenge for clinicians given poor quality evidence and risk adverse health outcomes, ${ }^{2,9-11}$ but presents an intense burden for people with kidney disease to implement day-to-day, and presents conflicting priorities which risk knockon health consequences.

\section{A move to dietary patterns: A potential paradigm shift in kidney disease}

The change in dietary management of chronic diseases from a single nutrient focus, towards the overall patterns of eating may address some of these concerns. Dietary patterns consider the cumulative effect and synergy between the combinations of foods and nutrients, which are more applicable to chronic disease management. ${ }^{41,42}$ Healthy dietary patterns with evidence for mitigating CVD risk include the Dietary Approaches to Stop Hypertension (DASH) diet, ${ }^{43}$ 
This is the peer reviewed version of the following article: Kelly, J. T., Rossi, M., Johnson, D. W., \& Campbell, K. L. (2017). Beyond Sodium, Phosphate and Potassium: Potential Dietary Interventions in Kidney Disease. Seminars in Dialysis, 30(3), 197-202, which has been published in final form at https://doi.org/10.1111/sdi.12580.

This article may be used for non-commercial purposes in accordance with Wiley Terms and Conditions for Use of Self-Archived Versions.

the Mediterranean diet, ${ }^{44}$ vegetarian diets, ${ }^{45,46}$ and patterns of eating consistent with dietary guidelines. ${ }^{47,48}$ Observational studies suggest these mentioned dietary patterns may be superior to single nutrient interventions, ${ }^{49}$ particularly due to the cumulative effects of multiple nutrients consumed through diets rich in fruit and vegetables,${ }^{50}$ fish and omega- 3 fatty acids,${ }^{51}$ legumes, wholegrain cereals and nuts, ${ }^{52}$ and lower in sodium,,${ }^{19}$ red meat, ${ }^{53}$ saturated fats, ${ }^{54}$ and common phosphate additives. ${ }^{55}$

There is a paucity of evidence for the effectiveness of changing dietary patterns in the established CKD population. However, emerging data supports dietary patterns that follow the Healthy Eating Index, DASH, and the Mediterranean diet to be associated with reduced renalrelated mortality and progression to ESKD. ${ }^{49,56,57}$ Preliminary data also suggest that adherence to the DASH diet may reduce the risk of ESKD incidence in people with established CKD, ${ }^{58}$ and a small single arm trial demonstrated the DASH diet as safe in a CKD sample. ${ }^{59}$ Other studies demonstrate that the DASH dietary pattern is associated with preserved residual kidney function and reduced overall incidence of CKD in community-dwelling individuals. ${ }^{56,60,61}$

Similarly, the Mediterranean diet has long-standing associations with reduced CVD incidence and mortality in the non-CKD population. ${ }^{62-65}$ Within the CKD population specifically, it appears that the Mediterranean diet may be particularly effective in reducing systemic inflammation and microalbuminuria. ${ }^{66}$ While no randomised controlled trials have been conducted in established CKD or dialysis populations to examine the effects of these diets on long-term patient-level outcomes, a recent meta-analysis of longitudinal studies demonstrated a healthy eating pattern was consistently associated with a $27 \%$ reduced risk of mortality in populations with established kidney disease. ${ }^{8}$

How can whole-of-diet approaches improve health outcomes? 
This is the peer reviewed version of the following article: Kelly, J. T., Rossi, M., Johnson, D. W., \& Campbell, K. L. (2017). Beyond Sodium, Phosphate and Potassium: Potential Dietary Interventions in Kidney Disease. Seminars in Dialysis, 30(3), 197-202, which has been published in final form at https://doi.org/10.1111/sdi.12580.

This article may be used for non-commercial purposes in accordance with Wiley Terms and Conditions for Use of Self-Archived Versions.

The opportunity to educate people with kidney disease to achieve a healthy dietary pattern presents itself with many benefits in comparison to isolated nutrient interventions. The translation of nutrient-based recommendations is exceptionally challenging for patients to quantify without ongoing guidance and feedback on daily consumption of these nutrients. ${ }^{34}$ In contrast, behavioural counselling to achieve a desired pattern of eating can lead to better compliance due to offering flexibility, choices to suit individual preferences, and a manageable change to a multitude of nutrients within the whole diet concurrently. ${ }^{34}$

Adopting a healthy dietary pattern has many mechanisms of benefit for cardiovascular health in $\mathrm{CKD}$, most notably through the increase in fruit, vegetables and a predominance of plantbased protein.

\section{Fruit and vegetables and cardiovascular health in kidney disease}

Fruit and vegetables generate bicarbonate naturally as they release potassium-salts and decrease the renal acid load. In-fact, a diet higher in fruit and vegetable has been shown to more effectively manage metabolic acidosis compared to standard bicarbonate prescriptions ${ }^{67}$ In contrast, sulphur containing animal proteins are naturally acid-producing and can exacerbate acidosis. ${ }^{58}$ Plant-based diets also limit the bioavailability of dietary phosphorus thereby decreasing absorption (due to the presence of phytate in vegetable forms of phosphorous), ${ }^{68}$ particularly in comparison to higher animal protein diets. ${ }^{45}$ Plant-based diets are also characteristically higher in fruit, vegetables and wholegrains, which increase the exposure to dietary fiber, which in turn is linked to reduced inflammation and improved survival. ${ }^{69}$

\section{Plant-based dietary patterns have different animal-plant protein ratios}

Altering the red meat-to-plant-based protein ratio to favour higher plant-based proteins has been described as likely 'kidney sparing' in CKD. ${ }^{53,70}$ Balanced portions from both red meat, fish and plant-based sources have been demonstrated in a cohort of 1355 haemodialysis patients 
This is the peer reviewed version of the following article: Kelly, J. T., Rossi, M., Johnson, D. W., \& Campbell, K. L. (2017). Beyond Sodium, Phosphate and Potassium: Potential Dietary Interventions in Kidney Disease. Seminars in Dialysis, 30(3), 197-202, which has been published in final form at https://doi.org/10.1111/sdi.12580.

This article may be used for non-commercial purposes in accordance with Wiley Terms and Conditions for Use of Self-Archived Versions.

to be associated with an appreciably lower risk of cardiovascular hospitalization death due to any cause compared with an unbalanced diet. ${ }^{71}$ However, despite the theoretical benefits of a plant-based diet, studies regarding the safety and efficacy of increased fruit and vegetable intake over the long term are lacking in both CKD and dialysis populations. This evidence gap needs addressing before such diets can become routinely recommended in the kidney disease population.

\section{Safety profile of a plant-based dietary pattern in the kidney disease population}

Safety concerns regarding plant-based diets relate to the high fruit and vegetable intake. However, fruit and vegetable intake is typically low across the CKD spectrum and unnecessary restriction may risk many vitamin and mineral insufficiencies. ${ }^{5}$ While fruit and vegetable intake conveys higher dietary potassium, it has been recently argued this does not necessarily translate into hyperkalaemia. ${ }^{72}$ It was also recently demonstrated that adults with stage 4 CKD can safely increase their servings of fruit and vegetables to correct metabolic acidosis and reduce blood pressure without an appreciably increased incidence of hyperkalaemia. ${ }^{73,74}$ In addition, a higher fiber intake from a higher fruit and vegetable diet can prevent constipation in dialysis populations and facilitate faecal excretion of excess potassium, which can be up to 3.5 times greater than that of the general population, and is directly associated with dietary intake. ${ }^{74}$ This ability of intestinal potassium excretion to compensate for a reduction in renal potassium handling has called into question the priority for dietary restriction in hyperkalemic states. ${ }^{72}$ Nonetheless, efficacy trials are needed to confirm the safety of plant-based diets.

\section{Dietary patterns and manipulation of the gut microbiome}

The bacterial community in the gut (termed the microbiota) contributes to digestion through fermentation and putrefaction, ${ }^{75}$ and is able to be manipulated by plant-based dietary patterns which emphasize whole grain carbohydrates, higher intakes of fibrous fruits, vegetables, 
This is the peer reviewed version of the following article: Kelly, J. T., Rossi, M., Johnson, D. W., \& Campbell, K. L. (2017). Beyond Sodium, Phosphate and Potassium: Potential Dietary Interventions in Kidney Disease. Seminars in Dialysis, 30(3), 197-202, which has been published in final form at https://doi.org/10.1111/sdi.12580.

This article may be used for non-commercial purposes in accordance with Wiley Terms and Conditions for Use of Self-Archived Versions.

legumes and nuts. ${ }^{75,76}$ Gut dysbiosis is commonly observed in kidney disease populations and is a major contributor to the build-up of uraemic toxins. Indoxyl sulphate (IS) and p-cresyl sulphate (PCS) are two uremic toxins produced by the gut microbiome, which originate from protein metabolism in the gut and are associated with increased CVD risk. ${ }^{77}$

It has been established that the concentration of these uremic toxins is increased by a high protein-to-fiber ratio in the diet. $^{78}$ Higher protein diets promote proteolytic (putrefaction) bacteria over saccharolytic (fermentation) bacteria, which in turn contributes to dysbiosis and a higher risk of CVD. ${ }^{79}$ Protein metabolism in the gut leads to the breakdown of tyrosine, phenylalanine, and tryptophan which are known precursor products for PCS and IS conversion. ${ }^{79}$ In contrast, the fermentation of fiber (non-digestible carbohydrate) releases shortchain fatty acids that are known to favour healthy microbial activity to control dysbiosis. ${ }^{80}$ Populations consuming a predominantly plant-based diet have greater microbiome abundance and biodiversity compared with populations consuming a diet subject to processing and inadequate fiber. ${ }^{81} \mathrm{~A}$ high fiber vegetarian diet has also been shown to reduce the production of IS and PCS compared to a high meat diet in a healthy population, ${ }^{46}$ which might translate to a reduced risk of CVD and mortality.

In the kidney disease population specifically, recent trials have demonstrated the roles of pre-biotics, ${ }^{82}$ pro-biotics, ${ }^{83}$ and their combination as synbiotics ${ }^{84}$ to modulate the composition of the intestinal microbiota, thereby controlling the production of IS and PCS, and ultimately potentially mitigating CVD risk and mortality. ${ }^{85}$ Improving the microbial diversity through synbiotics in kidney disease populations highlights an important role of the gut in mediating CVD risk, but also reaffirms the role of the overall quality of the diet. Specifically, a plant-based dietary pattern which contain natural pre-biotics ${ }^{86}$ and is lower in red meat proteins represents an important strategy for reducing uremic toxin production naturally. ${ }^{46}$ This dietary pattern is more likely to support the production of saccharolytic 
This is the peer reviewed version of the following article: Kelly, J. T., Rossi, M., Johnson, D. W., \& Campbell, K. L. (2017). Beyond Sodium, Phosphate and Potassium: Potential Dietary Interventions in Kidney Disease. Seminars in Dialysis, 30(3), 197-202, which has been published in final form at https://doi.org/10.1111/sdi.12580.

This article may be used for non-commercial purposes in accordance with Wiley Terms and Conditions for Use of Self-Archived Versions.

bacteria, generate short-chain fatty acids and improve cardiovascular risk and gastrointestinal health overall, beyond that of the single nutrient strategies targeting prebiotics, fiber, carbohydrates or protein in isolation. ${ }^{78,87}$

\section{Is a new paradigm shift in renal nutrition management on the horizon?}

People with kidney disease are advised to restrict individual nutrients, in line with current best practice guidelines. However, patients face several challenges from conflicting priorities which often result in poor compliance. Recent evidence supports a shift in nutritional focus to a healthy dietary pattern which is predominantly plant-based to promote control over a range of clinical risk factors and end-points in kidney disease. This is likely an approach which could facilitate compliance with dietary change in kidney disease. In addition, the non-invasive manipulation of the gut microbiota through a plant-based diet which is high in natural prebiotics has promising clinical potential.

It is now timely to determine whether a predominantly plant-based diet is feasible, safe and effective in the management of CKD and dialysis. To test the important question of whether the adoption of healthy eating patterns could improve patient-level outcomes in the kidney disease population, high quality controlled clinical trials are needed. However, until a plantbased dietary pattern has been deemed both safe and effective, and tested using a pragmatic implementation strategy, these theories of what exactly constitutes a 'healthy' diet will continue to be hypothetical. 
This is the peer reviewed version of the following article: Kelly, J. T., Rossi, M., Johnson, D. W., \& Campbell, K. L. (2017). Beyond Sodium, Phosphate and Potassium: Potential Dietary Interventions in Kidney Disease. Seminars in Dialysis, 30(3), 197-202, which has been published in final form at https://doi.org/10.1111/sdi.12580.

This article may be used for non-commercial purposes in accordance with Wiley Terms and Conditions for Use of Self-Archived Versions.

\section{References}

1. K/DOQI working group: $\mathrm{K} / \mathrm{DOQ}$ clinical practice guidelines on hypertension and antihypertensive agents in chronic kidney disease. American journal of kidney diseases : the official journal of the National Kidney Foundation 43: S1-290, 2004

2. Johnson DW, Atai E, Chan M, Phoon RK, Scott C, Toussaint ND, Turner GL, Usherwood T, Wiggins $\mathrm{KJ}$ : KHA-CARI Guideline: early chronic kidney disease: detection, prevention and management. Nephrology 18: 340-350, 2013

3. Palmer SC, Hanson CS, Craig JC, Strippoli GF, Ruospo M, Campbell K, Johnson DW, Tong A: Dietary and Fluid Restrictions in CKD: A Thematic Synthesis of Patient Views From Qualitative Studies. American journal of kidney diseases : the official journal of the National Kidney Foundation, 2014

4. Kalantar-Zadeh K, Tortorici AR, Chen JL, Kamgar M, Lau WL, Moradi H, Rhee CM, Streja E, Kovesdy $\mathrm{CP}$ : Dietary restrictions in dialysis patients: is there anything left to eat? Seminars in dialysis. Wiley Online Library, 2015, pp 159-168

5. Luis D, Zlatkis K, Comenge B, García Z, Navarro JF, Lorenzo V, Carrero JJ: Dietary quality and adherence to dietary recommendations in patients undergoing hemodialysis. Journal of Renal Nutrition 26: 190-195, 2016

6. de Jager DJ, Grootendorst DC, Jager KJ, van Dijk PC, Tomas LM, Ansell D, Collart F, Finne P, Heaf JG, De Meester J, Wetzels JF, Rosendaal FR, Dekker FW: Cardiovascular and noncardiovascular mortality among patients starting dialysis. Jama 302: 1782-1789, 2009

7. Lichtenstein AH, Appel LJ, Brands M, Carnethon M, Daniels S, Franch HA, Franklin B, Kris-Etherton P, Harris WS, Howard B: Diet and lifestyle recommendations revision 2006 A scientific statement from the American Heart Association nutrition committee. Circulation 114: 82-96, 2006

8. Kelly J, Campbell K, Wai S, Rouspo M, Carrero JJ, Palmer S, Strippoli GF: Healthy Eating Patterns, Mortality and End-Stage Kidney Disease in CKD: A Systematic Review and Meta-Analysis. Clin J Am Soc Neprol (in press) 11, 2016

9. Kidney Disease Outcomes Quality Initiative (K/DOQI): K/DOQI clinical practice guidelines on hypertension and antihypertensive agents in chronic kidney disease. American journal of kidney diseases : the official journal of the National Kidney Foundation 43: S1-290, 2004

10. Eknoyan G, Levin N: K/DOQI clinical practice guidelines for chronic kidney disease: Evaluation, classification, and stratification-Foreword. American Journal of Kidney Diseases 39: S14S266, 2002

11. Levin A, Hemmelgarn B, Culleton B, Tobe S, McFarlane P, Ruzicka M, Burns K, Manns B, White C, Madore F: Guidelines for the management of chronic kidney disease. Canadian Medical Association Journal 179: 1154-1162, 2008

12. National Collaborating Centre for Chronic Conditions \& Royal College of Physicians of London: Chronic kidney disease: national clinical guideline for early identification and management in adults in primary and secondary care. Royal College of Physicians, 2008

13. McMahon Emma J, Campbell Katrina L, Bauer Judith D, Mudge David W: Altered dietary salt intake for people with chronic kidney disease. Cochrane Database of Syst Rev: CD010070, 2015

14. Liu Z, Su G, Guo X, Wu Y, Liu X, Zou C, Zhang L, Yang Q, Xu Y, Ma W: Dietary interventions for mineral and bone disorder in people with chronic kidney disease. Cochrane Database of Syst Rev: CD010350, 2015

15. Fouque $D$, Laville M: Low protein diets for chronic kidney disease in non diabetic adults. Cochrane Database of Syst Rev: CD001892, 2009

16. Kotwal S, Jun M, Sullivan D, Perkovic V, Neal B: Omega 3 Fatty acids and cardiovascular outcomes: systematic review and meta-analysis. Circ Cardiovasc Qual Outcomes 5: 808-818, 2012 
This is the peer reviewed version of the following article: Kelly, J. T., Rossi, M., Johnson, D. W., \& Campbell, K. L. (2017). Beyond Sodium, Phosphate and Potassium: Potential Dietary Interventions in Kidney Disease. Seminars in Dialysis, 30(3), 197-202, which has been published in final form at https://doi.org/10.1111/sdi.12580.

This article may be used for non-commercial purposes in accordance with Wiley Terms and Conditions for Use of Self-Archived Versions.

17. Jones-Burton C, Mishra SI, Fink JC, Brown J, Gossa W, Bakris GL, Weir MR: An in-depth review of the evidence linking dietary salt intake and progression of chronic kidney disease. American journal of nephrology 26: 268-275, 2006

18. McMahon EJ, Bauer JD, Hawley CM, Isbel NM, Stowasser M, Johnson DW, Campbell KL: A randomized trial of dietary sodium restriction in CKD. J Am Soc Nephrol: ASN. 2013030285, 2013

19. McMahon EJ, Campbell KL, Bauer JD, Mudge DW: Altered dietary salt intake for people with chronic kidney disease. The Cochrane database of systematic reviews 2: Cd010070, 2015

20. Vegter S, Perna A, Postma MJ, Navis G, Remuzzi G, Ruggenenti P: Sodium intake, ACE inhibition, and progression to ESRD. JASN 23: 165-173, 2012

21. Vogt L, Waanders F, Boomsma F, de Zeeuw D, Navis G: Effects of dietary sodium and hydrochlorothiazide on the antiproteinuric efficacy of losartan. J Am Soc Nephrol 19: 9991007,2008

22. Suckling RJ, He FJ, MacGregor GA: Altered dietary salt intake for preventing and treating diabetic kidney disease. The Cochrane Library, 2010

23. Barsotti G, Giannoni A, Morelli E, Lazzeri M, Vlamis I, Baldi R, Giovannetti S: The decline of renal function slowed by very low phosphorus intake in chronic renal patients following a low nitrogen diet. Clinical nephrology 21: 54-59, 1984

24. Russo D, Miranda I, Ruocco C, Battaglia Y, Buonanno E, Manzi S, Russo L, Scafarto A, Andreucci V: The progression of coronary artery calcification in predialysis patients on calcium carbonate or sevelamer. Kidney international 72: 1255-1261, 2007

25. Aaron KJ, Sanders PW: Role of dietary salt and potassium intake in cardiovascular health and disease: a review of the evidence. Mayo Clinic Proceedings. Elsevier, 2013, pp 987-995

26. Korgaonkar S, Tilea A, Gillespie BW, Kiser M, Eisele G, Finkelstein F, Kotanko P, Pitt B, Saran R: Serum potassium and outcomes in CKD: insights from the RRI-CKD cohort study. Clinical journal of the American Society of Nephrology 5: 762-769, 2010

27. Mafra $D$, Barros AF, Fouque D: Dietary protein metabolism by gut microbiota and its consequences for chronic kidney disease patients. Future microbiology 8: 1317-1323, 2013

28. Klahr S, Levey AS, Beck GJ, Caggiula AW, Hunsicker L, Kusek JW, Striker G: The effects of dietary protein restriction and blood-pressure control on the progression of chronic renal disease. New England Journal of Medicine 330: 877-884, 1994

29. Fouque $D$, Laville $M$, Boissel J: Low protein diets for chronic kidney disease in non diabetic adults. The Cochrane database of systematic reviews 3, 2009

30. Kasiske BL, Lakatua J, Ma JZ, Louis TA: A meta-analysis of the effects of dietary protein restriction on the rate of decline in renal function. American Journal of Kidney Diseases 31: 954-961, 1998

31. Levey AS, Greene T, Beck GJ, Caggiula AW, Kusek JW, Hunsicker LG, Klahr S: Dietary Protein Restriction and the Progression of Chronic Renal Disease What Have All of the Results of the MDRD Study Shown? Journal of the American Society of Nephrology 10: 2426-2439, 1999

32. Klahr S, Levey AS, Beck GJ, Caggiula AW, Hunsicker L, Kusek JW, Striker G: The effects of dietary protein restriction and blood-pressure control on the progression of chronic renal disease. Modification of Diet in Renal Disease Study Group. The New England journal of medicine 330: 877, 1994

33. Naylor H, Jackson H, Walker G, Macafee S, Magee K, Hooper L, Stewart L, MacLaughlin H: British Dietetic Association evidence-based guidelines for the protein requirements of adults undergoing maintenance haemodialysis or peritoneal dialysis. Journal of Human Nutrition and Dietetics 26: 315-328, 2013

34. Mozaffarian D: Dietary and Policy Priorities for Cardiovascular Disease, Diabetes, and Obesity A Comprehensive Review. Circulation 133: 187-225, 2016 
This is the peer reviewed version of the following article: Kelly, J. T., Rossi, M., Johnson, D. W., \& Campbell, K. L. (2017). Beyond Sodium, Phosphate and Potassium: Potential Dietary Interventions in Kidney Disease. Seminars in Dialysis, 30(3), 197-202, which has been published in final form at https://doi.org/10.1111/sdi.12580.

This article may be used for non-commercial purposes in accordance with Wiley Terms and Conditions for Use of Self-Archived Versions.

35. Palmer SC, Hanson CS, Craig JC, Strippoli GF, Ruospo M, Campbell K, Johnson DW, Tong A: Dietary and fluid restrictions in CKD: a thematic synthesis of patient views from qualitative studies. Am J Kidney Dis 65: 559-573, 2015

36. McMahon EJ, Campbell KL, Mudge DW, Bauer JD: Achieving salt restriction in chronic kidney disease. Int J Nephrol 2012, 2012

37. Therrien M, Byham-Gray L, Beto J: A review of dietary intake studies in maintenance dialysis patients. Journal of Renal Nutrition 25: 329-338, 2015

38. Byham-Gray LD, Burrowes JD, Chertow GM: Nutrition in kidney disease. Springer Science \& Business Media, 2014

39. Shinaberger CS, Greenland S, Kopple JD, Van Wyck D, Mehrotra R, Kovesdy CP, Kalantar-Zadeh K: Is controlling phosphorus by decreasing dietary protein intake beneficial or harmful in persons with chronic kidney disease? The American journal of clinical nutrition 88: 15111518,2008

40. Goetze O, Fruehauf H, Pohl D, Giarre M, Rochat F, Ornstein K, Menne D, Fried M, Thumshirn M: Effect of a prebiotic mixture on intestinal comfort and general wellbeing in health. British journal of nutrition 100: 1077-1085, 2008

41. SchwingshackI L, Hoffmann G: Diet Quality as Assessed by the Healthy Eating Index, the Alternate Healthy Eating Index, the Dietary Approaches to Stop Hypertension Score, and Health Outcomes: A Systematic Review and Meta-Analysis of Cohort Studies. Journal of the Academy of Nutrition and Dietetics 115: 780-800. e785, 2015

42. US Department of Agriculture: A Series of Systematic Reviews on the Relationship Between Dietary Patterns and Health Outcomes. In: Agriculture, USDo (Ed.), 2014,

43. Appel LJ, Moore TJ, Obarzanek E, Vollmer WM, Svetkey LP, Sacks FM, Bray GA, Vogt TM, Cutler JA, Windhauser MM: A clinical trial of the effects of dietary patterns on blood pressure. The New England journal of medicine 336: 1117-1124, 1997

44. Panagiotakos DB, Pitsavos C, Arvaniti F, Stefanadis C: Adherence to the Mediterranean food pattern predicts the prevalence of hypertension, hypercholesterolemia, diabetes and obesity, among healthy adults; the accuracy of the MedDietScore. Preventive Medcine 44: 335-340, 2007

45. Moe SM, Zidehsarai MP, Chambers MA, Jackman LA, Radcliffe JS, Trevino LL, Donahue SE, Asplin $J R$ : Vegetarian compared with meat dietary protein source and phosphorus homeostasis in chronic kidney disease. Clinical Journal of the American Society of Nephrology 6: 257-264, 2011

46. Patel KP, Luo FJ-G, Plummer NS, Hostetter TH, Meyer TW: The production of p-cresol sulfate and indoxyl sulfate in vegetarians versus omnivores. Clinical Journal of the American Society of Nephrology 7: 982-988, 2012

47. Cespedes EM, Hu FB: Dietary patterns: from nutritional epidemiologic analysis to national guidelines. The American journal of clinical nutrition 101: 899-900, 2015

48. USDA: Scientific report of the 2015 Dietary Guidelines Advisory Committee. 2015,

49. Smyth A, Griffin M, Yusuf S, Mann JF, Reddan D, Canavan M, Newell J, O'Donnell M: Diet and Major Renal Outcomes: A Prospective Cohort Study. The NIH-AARP Diet and Health Study. Journal of Renal Nutrition, 2016

50. Wai S, Kelly J, Johnson D, Campbell K: Dietary Patterns and Clinical Outcomes in Chronic Kidney Disease: The CKD.QLD Nutrition Study. Journal of Renal Nutrition (In-Press) 27, 2016

51. Chrysohoou C, Pitsavos C, Panagiotakos D, Skoumas J, Lazaros G, Oikonomou E, Galiatsatos N, Striggou M, Xynogala M, Stefanadis C: Long-term fish intake preserves kidney function in elderly individuals: the Ikaria study. Journal of Renal Nutrition 23: e75-e82, 2013

52. Gutiérrez OM, Muntner P, Rizk DV, McClellan WM, Warnock DG, Newby PK, Judd SE: Dietary patterns and risk of death and progression to ESRD in individuals with CKD: a cohort study. American journal of kidney diseases 64: 204-213, 2014 
This is the peer reviewed version of the following article: Kelly, J. T., Rossi, M., Johnson, D. W., \& Campbell, K. L. (2017). Beyond Sodium, Phosphate and Potassium: Potential Dietary Interventions in Kidney Disease. Seminars in Dialysis, 30(3), 197-202, which has been published in final form at https://doi.org/10.1111/sdi.12580.

This article may be used for non-commercial purposes in accordance with Wiley Terms and Conditions for Use of Self-Archived Versions.

53. Lew Q-LJ, Jafar TH, Koh HWL, Jin A, Chow KY, Yuan J-M, Koh W-P: Red Meat Intake and Risk of ESRD. Journal of the American Society of Nephrology: ASN. 2016030248, 2016

54. Lin J, Judd S, Le A, Ard J, Newsome BB, Howard G, Warnock DG, McClellan W: Associations of dietary fat with albuminuria and kidney dysfunction. The American journal of clinical nutrition 92: 897-904, 2010

55. McCutcheon J, Campbell K, Ferguson M, Day S, Rossi M: Prevalence of Phosphorus-Based Additives in the Australian Food Supply: A Challenge for Dietary Education? Journal of Renal Nutrition 25: 440-444, 2015

56. Rebholz CM, Crews DC, Grams ME, Steffen LM, Levey AS, Miller ER, Appel L, Coresh J: DASH (Dietary Approaches to Stop Hypertension) Diet and Risk of Subsequent Kidney Disease. American Journal of Kidney Diseases, 2016

57. Díaz-López A, Bulló M, Martínez-González MÁ, Guasch-Ferré M, Ros E, Basora J, Covas M-I, del Carmen López-Sabater M, Salas-Salvadó J, Investigators PRS: Effects of Mediterranean diets on kidney function: a report from the PREDIMED trial. American Journal of Kidney Diseases 60: 380-389, 2012

58. Banerjee T, Liu Y, Crews D: Dietary Patterns and CKD Progression. Blood purification 41: 117-122, 2016

59. Tyson CC, Lin P-H, Corsino L, Batch BC, Allen J, Sapp S, Barnhart H, Nwankwo C, Burroughs J, Svetkey LP: Short-term effects of the DASH diet in adults with moderate chronic kidney disease: a pilot feeding study. Clinical Kidney Journal: sfw046, 2016

60. Crews DC, Kuczmarski MF, Miller rER, Zonderman AB, Evans MK, Powe NR: Dietary habits, poverty, and chronic kidney disease in an urban population. Journal of Renal Nutrition 25: 103-110, 2015

61. Lin J, Fung TT, Hu FB, Curhan GC: Association of dietary patterns with albuminuria and kidney function decline in older white women: a subgroup analysis from the Nurses' Health Study. American journal of kidney diseases : the official journal of the National Kidney Foundation 57: 245-254, 2011

62. Estruch R, Ros E, Salas-Salvado J, Covas MI, Corella D, Aros F, Gomez-Gracia E, Ruiz-Gutierrez V, Fiol M, Lapetra J, Lamuela-Raventos RM, Serra-Majem L, Pinto X, Basora J, Munoz MA, Sorli JV, Martinez JA, Martinez-Gonzalez MA: Primary prevention of cardiovascular disease with a Mediterranean diet. N Engl J Med 368: 1279-1290, 2013

63. Rees K, Hartley L, Flowers N, Clarke A, Hooper L, Thorogood M, Stranges S: 'Mediterranean' dietary pattern for the primary prevention of cardiovascular disease. Cochrane Database of Syst Rev: CD009825, 2013

64. Sofi F, Cesari F, Abbate R, Gensini GF, Casini A: Adherence to Mediterranean diet and health status: meta-analysis. BMJ 337, 2008

65. Trichopoulou A, Bamia C, Trichopoulos D: Anatomy of health effects of Mediterranean diet: Greek EPIC prospective cohort study. BMJ 338, 2009

66. De Lorenzo A, Noce A, Bigioni M, Calabrese V, Della Rocca D, Daniele N, Tozzo C, Renzo LD: The effects of Italian Mediterranean organic diet (IMOD) on health status. Current pharmaceutical design 16: 814-824, 2010

67. Goraya N, Simoni J, Jo CH, Wesson DE: A comparison of treating metabolic acidosis in CKD stage 4 hypertensive kidney disease with fruits and vegetables or sodium bicarbonate. Clin J Am Soc Nephrol 8: 371-381, 2013

68. Calvo MS, Uribarri J: Contributions to total phosphorus intake: all sources considered. Seminars in dialysis. Wiley Online Library, 2013, pp 54-61

69. Krishnamurthy VM, Wei G, Baird BC, Murtaugh M, Chonchol MB, Raphael KL, Greene T, Beddhu S: High dietary fiber intake is associated with decreased inflammation and all-cause mortality in patients with chronic kidney disease. Kidney Int 81: 300-306, 2012 
This is the peer reviewed version of the following article: Kelly, J. T., Rossi, M., Johnson, D. W., \& Campbell, K. L. (2017). Beyond Sodium, Phosphate and Potassium: Potential Dietary Interventions in Kidney Disease. Seminars in Dialysis, 30(3), 197-202, which has been published in final form at https://doi.org/10.1111/sdi.12580.

This article may be used for non-commercial purposes in accordance with Wiley Terms and Conditions for Use of Self-Archived Versions.

70. National Kidney Foundation: KDOQI Clinical Practice Guidelines and Clinical Practice Recommendations for Diabetes and Chronic Kidney Disease. American journal of kidney diseases : the official journal of the National Kidney Foundation 49: S1-S180., 2007

71. Tsuruya K, Fukuma S, Wakita T, Ninomiya T, Nagata M, Yoshida H, Fujimi S, Kiyohara Y, Kitazono T, Uchida K, Shirota T, Akizawa T, Akiba T, Saito A, Fukuhara S: Dietary patterns and clinical outcomes in hemodialysis patients in Japan: a cohort study. PLoS One 10: e0116677, 2015

72. St-Jules DE, Goldfarb DS, Sevick MA: Nutrient Non-equivalence: Does Restricting High-Potassium Plant Foods Help to Prevent Hyperkalemia in Hemodialysis Patients? Journal of Renal Nutrition, 2016

73. Mathialahan T, Maclennan K, Sandle L, Verbeke C, Sandle G: Enhanced large intestinal potassium permeability in end-stage renal disease. The Journal of pathology 206: 46-51, 2005

74. Hayes Jr C, McLeod M, Robinson R: An extravenal mechanism for the maintenance of potassium balance in severe chronic renal failure. Transactions of the Association of American Physicians 80: 207-216, 1966

75. Montemurno E, Cosola C, Dalfino G, Daidone G, De Angelis M, Gobbetti M, Gesualdo L: What would you like to eat, Mr CKD Microbiota? A Mediterranean Diet, please! Kidney and Blood Pressure Research 39: 114-123, 2014

76. David LA, Maurice CF, Carmody RN, Gootenberg DB, Button JE, Wolfe BE, Ling AV, Devlin AS, Varma Y, Fischbach MA: Diet rapidly and reproducibly alters the human gut microbiome. Nature 505: 559-563, 2014

77. Rossi M, Campbell K, Johnson D, Stanton T, Pascoe E, Hawley C, Dimeski G, McWhinney B, Ungerer J, Isbel N: Uraemic toxins and cardiovascular disease across the chronic kidney disease spectrum: an observational study. Nutrition, Metabolism and Cardiovascular Diseases 24: 1035-1042, 2014

78. Rossi M, Johnson DW, Xu H, Carrero J, Pascoe E, French C, Campbell K: Dietary protein-fiber ratio associates with circulating levels of indoxyl sulfate and $p$-cresyl sulfate in chronic kidney disease patients. Nutrition, Metabolism and Cardiovascular Diseases 25: 860-865, 2015

79. Evenepoel P, Meijers BK, Bammens BR, Verbeke K: Uremic toxins originating from colonic microbial metabolism. Kidney International 76: S12-S19, 2009

80. den Besten G, van Eunen K, Groen AK, Venema K, Reijngoud D-J, Bakker BM: The role of shortchain fatty acids in the interplay between diet, gut microbiota, and host energy metabolism. Journal of lipid research 54: 2325-2340, 2013

81. Schnorr SL, Candela M, Rampelli S, Centanni M, Consolandi C, Basaglia G, Turroni S, Biagi E, Peano C, Severgnini M: Gut microbiome of the Hadza hunter-gatherers. Nature communications 5, 2014

82. Meijers BK, De Preter V, Verbeke K, Vanrenterghem Y, Evenepoel P: $p$-Cresyl sulfate serum concentrations in haemodialysis patients are reduced by the prebiotic oligofructoseenriched inulin. Nephrology Dialysis Transplantation: gfp414, 2009

83. Takayama F, Taki K, Niwa T: Bifidobacterium in gastro-resistant seamless capsule reduces serum levels of indoxyl sulfate in patients on hemodialysis. American journal of kidney diseases : the official journal of the National Kidney Foundation 41: S142-145, 2003

84. Rossi M, Johnson DW, Morrison M, Pascoe EM, Coombes JS, Forbes JM, Szeto C-C, McWhinney $\mathrm{BC}$, Ungerer JP, Campbell KL: Synbiotics easing renal failure by improving gut microbiology (SYNERGY): A randomized trial. Clinical Journal of the American Society of Nephrology: CJN. 05240515, 2016

85. Rossi M, Klein K, Johnson DW, Campbell KL: Pre-, pro-, and synbiotics: do they have a role in reducing uremic toxins? A systematic review and meta-analysis. International journal of nephrology 2012, 2012

86. Wichienchot $S$, Thammarutwasik $P$, Jongjareonrak A, Chansuwan W, Hmadhlu $P$, Hongpattarakere $\mathrm{T}$, Itharat $\mathrm{A}$, Ooraikul B: Extraction and analysis of prebiotics from selected 
This is the peer reviewed version of the following article: Kelly, J. T., Rossi, M., Johnson, D. W., \& Campbell, K. L. (2017). Beyond Sodium, Phosphate and Potassium: Potential Dietary Interventions in Kidney Disease. Seminars in Dialysis, 30(3), 197-202, which has been published in final form at https://doi.org/10.1111/sdi.12580.

This article may be used for non-commercial purposes in accordance with Wiley Terms and Conditions for Use of Self-Archived Versions.

plants from southern Thailand. Sonklanakarin Journal of Science and Technology 33: 517, 2011

87. Xu H, Rossi M, Campbell KL, Sencion GL, Ärnlöv J, Cederholm T, Sjögren P, Risérus U, Lindholm B, Carrero J: Excess protein intake relative to fiber and cardiovascular events in elderly men with chronic kidney disease. Nutrition, Metabolism and Cardiovascular Diseases 26: 597-602, 2016 